\title{
The California College Preparatory Academy: An Enduring School-University Partnership
}

\section{Summary}

Partnerships between universities and $K-12^{1}$ schools have a long history in the United States. The early partnerships typically involved elite or selective schools that catered to children from affluent households or children of academics. In the past few decades, a third wave of university schools has opened. These schools have a social justice and equity focus and are intended to provide quality educational experiences to children from low-income backgrounds and children from groups underrepresented in tertiary education. The California College Preparatory Academy (CAL Prep) is a member of this third wave and one of several school-university partnerships involving University of California campuses. CAL Prep opened in 2005 and is an ongoing partnership involving Aspire Pubic Schools and the University of California, Berkeley. This article provides a description of CAL Prep, and an overview of the circumstances that led to CAL Prep's formation. The partnership structures, which contributed to the longevity of the partnership, are also described.

Keywords: CAL Prep, co-construction, collaboration, school-university partnership

\section{Die California College Preparatory Academy: eine nachhaltige Zusammenarbeit zwischen Schule und Universität}

\section{Zusammenfassung}

Partnerschaften zwischen Universitäten und K-12-Schulen [Schulen, die vom Kindergarten bis zur zwölften Klasse führen] haben in den USA eine lange Geschichte. Die ersten Partnerschaften bestanden meist mit Eliteschulen, die entweder von Kindern aus wohlhabendem Elternhaus oder von Akademikerkindern besucht wurden. In den letzten Jahrzehnten kam es zur Gründung einer dritten Form von Universitätsschulen. Diesen Schulen geht es vor allem um soziale Gerechtigkeit und Chancengleichheit; sie sollen Kindern aus einkommensschwachen Elternhäusern und Kindern mit bildungsferner Herkunft eine qualifizierte Bildung bieten. Die California College Preparatory Academy

1 The expression " $\mathrm{K}-12$ " is a shortening and means: from kindergarten $(=\mathrm{K})$ for 4 - to 6-yearolds through twelfth grade (12) for 17- to 19-year-olds. 
(CAL Prep) gehört zu dieser dritten Gruppe; es handelt sich bei ihr um eine von mehreren Partnerschaften zwischen Universitäten und Schulen in Kalifornien. Die CAL Prep wurde im Jahre 2005 gegründet und beruht auf der Partnerschaft zwischen Aspire Public Schools und der University of California, Berkeley. Dieser Beitrag stellt die CAL Prep vor und erläutert die Umstände, die zu ihrer Gründung geführt haben. Außerdem werden die Strukturen beschrieben, die die Nachhaltigkeit dieser Partnerschaft gesichert haben.

Schlüsselwörter: Universitätsschule, Ko-Konstruktion, Kollaboration, Partnerschaft zwischen Universität und Schule

There is a long history of university-affiliated schools in the United States, dating back to 1768 (Cucciara, 2010). However, these early schools, typically run by selective institutions of higher education, were private institutions that catered to the upper classes. In the $19^{\text {th }}$ century, a second set of university-affiliated schools came into existence. These were laboratory schools intended to serve as demonstration schools for research or teacher training. Despite this goal, these schools also served primarily elite student populations, such as children of the university faculty (Cucciara, 2010; Lauderdale, 1981). Consequently, they proved less than ideal places to examine the education system's failure to serve children from low-income and minority backgrounds. In the last few decades, there has been a third wave of university-affiliated schools developed with a focus on equity and social justice and the intention to provide quality education to students at the lower end of the longstanding achievement gaps (Mehan, Kaufman, Lytle, Quartz \& Weinstein, 2010; Quartz et al., 2017).

The California College Preparatory Academy (CAL Prep), founded in 2005 in partnership with the University of California, Berkeley, is part of this third wave (Weinstein \& Worrell, 2016b). In this article, I briefly review the circumstances that led Berkeley to found CAL Prep and describe the structures put in place to allow for a robust and enduring partnership. The information in this article is drawn from notes on the project and Achieving College Dreams (Weinstein \& Worrell, 2016a), a book, which provides a historical chronicle of CAL Prep from the genesis of the idea for the school in 2002 through the graduation of the school's second cohort in 2012.

\section{The California College Preparatory Academy (CAL Prep)}

CAL Prep is a public charter school, serving students in Grades 6 to 12. It opened its doors in 2005 with 90 students in Grades 6 and 7 in a school building in Oakland, California, which is contiguous to the city of Berkeley. It is currently located in Richmond, California, approximately seven miles from Berkeley, and has a student body of 520 students. Students from ethnic minority backgrounds make 
up the majority of the students. Hispanic or Latino students constitute the largest group (67.6\%), and fewer than 4 percent are students of European American descent. Almost two-thirds (65\%) of the students qualify for free and reduced lunch, and 27 percent are English Language learners.

The genesis of a school affiliated with the UC Berkeley did not originate with the campus. In 2002, UC Berkeley received a letter from Professor Anthony Marx inviting the university to apply for a grant to start an early college high school, as part of a program supported by the Bill and Melinda Gates Foundation. That foundation had decided to support the development of university-affiliated, early college high schools in which students from low-income and minority backgrounds earned college credit and an Associate degree in their final two years of high school, based on the premise that with more college credits under their belts, students attending these schools would be more likely to complete a Bachelor's degree. This initiative had not been embraced by selective institutions, and Professor Marx's hope was that UC Berkeley's historic and ongoing commitment to social justice would lead to its involvement.

Several concerns were raised by university faculty and administrators about UC Berkeley's participation in this project. One of the major concerns was the lack of expertise at the university in running K-12 schools. Other concerns included the extent of the financial commitment and liability on the part of the university and the impact on the university's reputation if the school was not successful. There was also a concern on the part of the Graduate School of Education (GSE) that a successful endeavor would be seen as a success of the campus, but an unsuccessful endeavor would be attributed to the GSE. Ultimately, the decision was made to move forward with the project, in part due to several factors, including (a) the concern about the state's shrinking financial commitment to $\mathrm{K}-12$ outreach, (b) the fact that the funders allowed Berkeley to propose an early college secondary school (i. e., Grades 6 to 12) instead of just a high school (Grades 9 to 12), and (c) several individuals in influential positions at the university who championed the project.

\section{Influential Supporters}

One of the influential champions was David Pearson, Dean of the GSE from 2001 to 2010, who saw the project as an opportunity for the GSE to be a leader in the field and on the UC Berkeley campus:

\footnotetext{
"Relatively early in my deanship at the Graduate School of Education at the University of California (UC) Berkeley, we were asked to consider sponsoring an early college high school [...]. When presented with this opportunity, I jumped at the chance. What could be better for a graduate school of education in a prestigious Research I institution than being a part of an effort to increase academic opportunity
} 
for traditionally marginalized students [...] my motives were as personal as they were institutional. UC Berkeley had been my ticket to academic capital in the early 1960s [...] so I knew it could change the lives of lots of poor kids who might attend the California College Preparatory Academy (CAL Prep)." (Kaufman, Jorgensen, Padilla \& Pearson, 2016, p. 43)

A second influential champion was the Vice Chancellor for Student Affairs, Genaro Padilla. His support was based in part on the decreasing numbers of underrepresented students on the Berkeley campus, due in part to the passage of Proposition 209, which banned public universities in California from using race as a factor in university admissions.

"While I was Vice Chancellor for Student Affairs, we underwent a sustained admissions crisis. The number and percentage of low income, first-generation, underrepresented students admissible to the University of California (UC) Berkeley fell by well over $50 \%$. It was clear to many of us that the California public schools were failing many of our children, so when a group of staff members suggested we consider building a charter school that would demonstrate our ability to model a successful learning environment I was intrigued [...]. Additionally, as a Chicano and one of the very few faculty of color here at UC Berkeley, I wanted to be part of an enterprise that would resonate with my own social values and my sense of outrage that, with respect to Latinos alone, so few students even had a shot at admission to universities such as UC Berkeley." (Kaufman et al., 2016, p. 38)

Thus, the sociohistorical context contributed to the climate in support of starting the school.

There were several other champions of the project. One was Professor Rhona Weinstein, a community psychologist in the Department of Psychology, who conducted research in schools, specifically studying the dynamics of low expectations on the schooling outcomes of youth from low-socioeconomic status and minority backgrounds. Professor Worrell in Education was also supportive of the project. His training was as an educational and school psychologist, and his research interests focused on the factors that lead youth to drop out of or excel at school. Perhaps the most ardent advocate was Gail Kaufman, a staff member who served as Deputy Director of the Center for Educational Partnerships (CEP) at UC Berkeley, where she coordinated the work on creating college-going culture in K-12 schools. The university's educational outreach had been severely curtailed by budget cuts, and Ms. Kaufman was the individual on whose desk the letter arrived for consideration, via the Chancellor, Vice Chancellor Padilla, and the CEP director. She was asked to look into the opportunity that the letter represented and, after concluding that the school was a worthwhile endeavor, she became a passionate proponent for moving forward, working tirelessly to support the project both before and after the school started. I now turn to the elements that led to the sustainability of the CAL Prep partnership. 


\section{Building a Robust Partnership}

The initial grant from the Foundations was intended to provide a limited amount of funds for planning and development. However, sustaining a school would require a lot more investment on the part of the institution. If the university were to get involved in a school partnership, the commitment had to be long-term. Unlike a grant, which ends after a few years, a school would exist long into the future. Below, I detail some of the elements that resulted in a robust partnership, which has been sustained for almost 15 years. These elements included making the school a university-wide endeavor, finding a partner who was also willing to commit for the long term, and putting structures, resources, and time commitments in place that support the ongoing collaboration.

Making CAL Prep a university-wide endeavor. Projects will typically not receive endorsement and support from the campus administration unless tenure-line faculty are committed and actively involved. The initial supporters included Dean Pearson of the GSE and Vice Chancellor Padilla in Student Affairs. They invited Professor Marx to the campus to talk to UC Berkeley faculty about the early college high school so that faculty members could hear about the project from another academic. These meetings took place in April and May of 2003, as well as meetings with the academic senate, and the outcome was that CAL Prep became a university-wide endeavor with participation from faculty from several campus departments. An advisory committee of 14 individuals was appointed by the Chancellor to guide the Early College Initiative (see Table 1 on the next page).

As Table 1 indicates, there were five faculty members from education, six faculty members from departments other than education, a doctoral student from education, and two staff members, one from education and one from outside education, and two participants from the Charter partner, including the CAL Prep principal. An important point for the project is that it was conceived of as a long-term endeavor. Thus, the initial term of appointment to the Advisory Committee was four years, although several individuals served for much longer terms. Thus, CAL Prep was not just a project of the GSE, although the GSE was the lead department. In subsequent years, individuals joined the Committee from Social Welfare and the History and Social Science Project, and a public member was also added. To facilitate scheduling and the longterm commitment, the Advisory Committee meetings were scheduled for the second Monday of each month from 3 to $5 \mathrm{pm}$ from September to May. This advisory committee met regularly from October, 2003 through March, 2016. 
Table 1: Individuals Serving on the Initial Advisory Committee for the CAL Prep Project

\begin{tabular}{lll}
\hline Faculty Member & Department & Other Role \\
\hline${ }^{1}$ Gibor Basri & Astronomy & Became Berkeley's 1 \\
Brent Duckor & Education & Graduate Student in Education \\
${ }^{2}$ Elise Darwish & Aspire & Regional Superintendent for Aspire Public Schools \\
${ }^{1}$ Ronald Gronsky & Engineering & Incoming Chair of the Academic Senate \\
${ }^{1}$ Neil Henry & Journalism & \\
${ }^{3}$ Robert E. Jorgensen & Education & Staff Liaison to CAL Prep \\
${ }^{3}$ Gail Kaufman & CEP & Staff Liaison to CAL Prep, Deputy Director of CEP \\
${ }^{1}$ Genaro M. Padilla & English & Vice Chancellor for Student Affairs \\
${ }^{1}$ P. David Pearson & Education & Dean, Graduate School of Education \\
${ }^{4}$ Michael Prada & Aspire & Principal of CAL Prep \\
${ }^{1}$ Ingrid Seyer-Ochi & Education & \\
${ }^{1}$ Angelica Stacy & Chemistry & Co-Chair of the Advisory Committee \\
${ }^{1}$ David Stern & Education & $\begin{array}{l}\text { Co-Chair of the Advisory Committee } \\
\text { (3 years) }\end{array}$ \\
${ }^{1}$ Rhona S. Weinstein & Psychology & Co-Faculty Director of Project \\
${ }^{1}$ Mark Wilson & Education & Co-Chair of the Advisory Committee \\
& (2 years) \\
${ }^{1}$ Frank C. Worrell & Education & Co-Faculty Director of Project \\
\hline
\end{tabular}

Note. $\quad \mathrm{CEP}=$ Center for Educational Partnerships. ${ }^{1}$ Professors. ${ }^{2}$ Began participating in meetings after Aspire became the partner district. ${ }^{3}$ Served as Committee Staff. ${ }^{4}$ First principal of CAL Prep, who began attending ECI meetings a few months before the school opened; subsequent principals continued to attend the ECI meetings.

Finding a committed partner. One of the debates that emerged had to do with who would run the school. Interestingly, UC San Diego had opened a partnership secondary school in 1999, and this school was run by the university. Major partners in the UC San Diego endeavor advised against UC Berkeley running the school. After conversations and site visits, UC Berkeley decided to partner with Aspire Public Schools, a charter management organization (CMO). As a university that has historically been aligned with the labor movement and unions, choosing to partner with a CMO was a major step and a difficult choice. Although charter schools are public schools, most of these schools are non-union employers and the university reflects and is an ardent supporter of non-charter public schooling.

The final decision to choose Aspire was based on several factors (Weinstein, 2016b). First, Aspire was willing to allow Berkeley to co-construct the school with them, which allowed us to build the school "from scratch." If we partnered with an existing district, we would have inherited a school and would have had to get permission from parents, the school board, teachers and their union to restructure a school. And even if those permissions were acquired, they would be subject to renegotiation with every new district superintendent, school principal, and union contract, as would the decisions to make major changes. This hurdle, coupled with experiences of some of 
the faculty who had had longstanding research projects terminated in public schools with a change in administration helped in making the final decision to partner with the CMO.

The willingness to truly collaborate. The commitment to collaborate was ratified in a Memorandum of Understanding (MOU) signed by UC Berkeley and Aspire Public Schools on October 26, 2005. As stated in the MOU,

"this collaborative effort by University and Aspire will combine the implementation of vigorous educational methods with the opportunity for high quality research and design" (Memorandum of Understanding between the Regents of the University of California and Aspire Public Schools, 2005, p. 1).

However, more important than the dispute resolution clauses and the ways in which the parties could dissolve the partnership were the specific agreements around the way the collaboration would work. The MOU stipulated that Aspire would obtain the Charter for the school and would be responsible for its operation and management. However, UC Berkeley's name would be included in the charter petition and the university would provide policy advice and guidance and participate in decision-making. It was also agreed that Aspire and UC Berkeley "would participate in consistent and transparent consultation on all educational issues affecting the School" (MOU, 2005, p. 5).

The division of responsibilities as outlined in the MOU can be seen in Table 2 (next page). Listed first are the joint responsibilities, which were to be decided by consensus. For example, Professor Worrell co-chaired the Search Committee for the School's first principal and he and other UC Berkeley personnel have been involved in hiring every CAL Prep principal since. Aspire took the lead on the regular school functions, whereas UC Berkeley took the lead on research and curriculum. It is important to note that decisions have been made jointly by all parties, and there have not been any formal disputes about authority. Indeed, UC Berkeley has probably abrogated responsibility more than Aspire, but it is also worth noting that although the MOU was intended to be in place for a five year period, subject to renewal, the MOU was never revisited. Indeed, the MOU had long expired in 2010 before it was given any thought and the partnership has continued without an active MOU in force.

Additional structures. UC Berkeley has a well-known reputation for faculty involvement in governance activities. The instantiation of this involvement is via committee service. As noted earlier in this paper, the ECI Advisory Committee was appointed by the Chancellor and had monthly meetings. There were two other regular meetings that were critical to the partnership's longevity. One of these took place at CAL Prep and the other took place on the university's campus. 
Table 2: Division of Responsibilities between Aspire Public Schools and UC Berkeley

\begin{tabular}{lll}
\hline Joint Responsibility & Aspire Public Schools & UC Berkeley \\
\hline Hiring School Leadership & School Calendar and Schedule & Principles of School Culture \\
Work Environment & Implementation & Enrollment Policy and Outreach \\
Supporting Teacher Professionalism & School Culture & Strategy \\
Assessments & Scholastic Program and Reporting & Curriculum and Instructional \\
Students Enrolling in College & Parent/Care Giver Relations & Design \\
Courses & Volunteer Planning and Imple- & Research On-Site \\
Fundraising & mentation & Research on Charter Schooling \\
Grants and Contracts & Human Resource Systems & Placement of GSE Student \\
Media Relations & Financial Systems & Teachers \\
Site Selection & Facilities Systems & Professional Learning for the \\
Facility Design & Legal Compliance & External Education Community \\
\hline
\end{tabular}

Note. The information in this table is taken from the Memorandum of Understanding signed by UC Berkeley and Aspire Public Schools in 2005 in relation to the establishment of the CAL Prep partnership.

UC Berkeley liaisons meeting. Two faculty members and two staff members were appointed as university liaisons to CAL Prep. They included Gail Kaufman (staff liaison from CEP), Robert Jorgensen (staff liaison from the GSE), Rhona Weinstein (faculty liaison from Psychology), and Frank Worrell (faculty liaison from the GSE). This group of individuals met every week until the summer of 2018 with some attrition. Professor Weinstein retired in 2007, but continued to serve for several years on the ECI. Mr. Jorgensen retired from the university in 2009. Ms. Kaufman and Professor Worrell continued to meet until Ms. Kaufman's retirement in the summer of 2018. This meeting allowed the key university partners to discuss ongoing events at the school, and serve as effective conduits between the university and the CAL Prep. As the members of this group attended the ECI meetings, as well as the meetings at the school site, they were able to facilitate the ongoing relationship among CAL Prep, Aspire Public Schools, and UC Berkeley.

School-site partnership meeting. There was also a weekly meeting at the school site, which included the four university liaisons, the CAL Prep principal, the Aspire Public Schools regional superintendent for the Bay Area (i.e., the CAL Prep Principal's supervisor), and, on some occasions, CAL Prep teacher representatives. This group worked on co-constructing the school as called for in the MOU and made decisions on a wide range of topics. Using data collected from the school, the attendees at the school-site partnership meetings discussed curriculum, student preparedness, communication with parents, teacher effectiveness, and any other concerns that came up. This group also reviewed and approved all proposals for research at the school site.

Time and other resources. Another important aspect of support for this project was the commitment of resources by the university, including the critical resource of time. 
The university assigned one of the staff members in the development office to the CAL Prep project, such that she could devote half of her time to raising funds to support the partnership. Ms. Kaufman's assignment was changed such that she devoted half of her time to the project as well. Both Professors Weinstein and Worrell were given a one-course reduction so that they could devote time to the partnership, a one-course release that Professor Worrell still has. Finally, the university supported a half-time graduate research assistant for about five years. After this support ended, resources have been found by the partners to support the process. For example, Professor Worrell had a post-doctoral fellow from 2016 to 2018 who was tasked with doing research on the early college schools including the CAL Prep partnership as half of his duties, and in year 2018, CAL Prep receives five hours a week of support from a graduate student researcher assigned to Professor Worrell.

On the ground commitments by university personnel. Education practitioners often discount the perspectives of education researchers as esoteric and not in touch with the reality of what happens in the classroom on a daily basis. This project contributed to dispelling this notion, at least for the faculty involved. In addition to conducting research studies on parent involvement (e.g., Sami, Worrell \& Weinstein, 2016) and tracking student academic progress (e.g., Weinstein, Martin, Bialis-White \& Sami, 2016), university faculty were intimately connected with multiple aspects of CAL Prep. In the first year, when there were few extracurricular activities, Professor Worrell, who conducts a choir for the GSE, also started a choir at CAL Prep, which did a joint concert with the GSE choir at the end of the year (Weinstein, 2016a). He also supervised a student counselor at the school site before the school had its own counselor, and School Psychology Program continues to place practicum students at the site.

Professor Weinstein developed a student advisory curriculum, trained school personnel on how to implement it, and evaluated the outcomes of the curriculum to inform (Weinstein, Sami \& Mello, 2016). And a graduate student in the doctoral program in language and literacy education built the CAL Prep library from scratch with input from students and teachers (Goodin \& Pearson, 2016); this project was used for her doctoral dissertation supervised by Dean Pearson. Additional projects are documented in several chapters in Weinstein and Worrell (2016a).

\section{Conclusion}

It would be dishonest to pretend that the partnership always proceeded smoothly (Weinstein, Worrell, Kaufman \& Basri, 2016). Indeed, there were many times when difficult dialogues needed to be had. UC Berkeley faculty objected to practices that they felt were not supported in the literature, but did so in collegial ways and had to 
provide evidence to support their claims. Sometimes, that evidence took the form of data from a research project at the school or a look at the outcomes of the intervention or practice. The two institutions also had differing timelines for decision-making. Aspire noted that they were playing "Pac Man" whereas UC Berkeley was playing "chess" (Darwish \& Epanchin-Troyan, 2016). Nonetheless, the school reported and continues to report positive outcomes. The students all have an acceptance letter to a four-year institution when they leave Cal Prep, a graduation requirement, and they outperform their peers from similar demographic backgrounds.

In the past few years, the challenges have continued. Many of the individuals who have retired have not yet been replaced. The ECI no longer meets regularly, and the CAL Prep Principal has just been promoted to Regional Superintendent for Southern California, beginning in October of 2018. However, in communicating the news of his promotion, the Aspire Superintendent also asked to schedule meeting with Berkeley to discuss the search for the new principal, albeit with no MOU in place since 2010. CAL Prep was a co-constructed entity and the structures developed to support it were structures aimed at supporting a "start-up" venture. The discussions now center on how we change the partnership structures to support a mature school beginning its $14^{\text {th }}$ year. And so, the partnership endures.

"CAL Prep's success is not due to technology or a focus on the science, technology, engineering and mathematics disciplines, or any other singular trend in education. Rather, CAL Prep's outcomes come from a true district-university partnership based on mutual respect for the expertise that the partners bring, a joint recognition that complex problems require multivariate solutions, and a commitment to the ongoing, sometimes tedious, and ever-evolving tasks by all of the partners - sweat equity if you will - to do what must be done." (Worrell \& Weinstein, 2016, pp. 394395)

\section{References}

Cucciara, M. (2010, Summer). New Goals, Familiar Challenges? A Brief History of University-run Schools. Perspectives on Urban Education, 96-108. Retrieved from http://www.urbanedjournal.org/sites/urbanedjournal.org/files/pdf_archive/PUESummer2010-V7I1-pp96-108.pdf.

Darwish, E., \& Epanchin-Troyan, T. (2016). From Parallel Tracks to Intertwined Efforts: Aspire Public Schools Reflects. In R.S. Weinstein \& F.C. Worrell (Eds.), Achieving College Dreams: How a University-Charter District Partnership Created an Early College High School (pp. 33-53). New York: Oxford University Press. doi.org/10.1093/acprof:o so/9780190260903.003.0016

Goodin, M., \& Pearson, P.D. (2016). Making Room to Read: The Evolution of a Secondary School Library. In R.S. Weinstein \& F.C. Worrell (Eds.), Achieving College Dreams: How a University-Charter District Partnership Created an Early College High School (pp. 163-184). New York: Oxford University Press. doi.org/10.1093/acprof:oso/ 9780190260903.003.0008 
Kaufman, G., Jorgensen, R.E., Padilla, G.M., \& Pearson, P.D. (2016). The University of California, Berkeley Commits. In R.S. Weinstein \& F.C. Worrell (Eds.), Achieving College Dreams: How a University-Charter District Partnership Created an Early College High School (pp. 33-53). New York: Oxford University Press. doi.org/10.1093/acprof:o so/9780190260903.003.0002

Lauderdale, W.B. (1981). Progressive Education: Lessons from Three Schools. Bloomington, IN: Phi Delta Kappan Educational Foundation.

Mehan, H., Kaufman, G., Lytle, C., Quartz, K.H., \& Weinstein, R.S. (2010). Building Educational Field Stations to Promote Diversity and Access in Higher Education. In E. Grodsky \& M. Kurlaender (Eds.), Equal Opportunity in Higher Education: The Past and Future of California's Proposition 209 (pp. 173-193). Cambridge, MA: Harvard Education Press.

MOU (2005). Memorandum of Understanding between the Regents of California and Aspire Public Schools. Unpublished Document.

Quartz, K.H., Weinstein, R.S., Kaufman, G., Levine, H., Mehan, H., Worrell, F.C., et al. (2017). University-Partnered New School Designs: Fertile Ground for ResearchPractice Partnerships. Educational Researcher, 46, 143-146. doi.org/10.3102/0013189X 17703947

Sami, N., Worrell, F.C., \& Weinstein, R.S. (2016). Parent Involvement and the HomeSchool Divide. In R.S. Weinstein \& F.C. Worrell (Eds.), Achieving College Dreams: How a University-Charter District Partnership Created an Early College High School (pp. 143-161). New York: Oxford University Press. doi.org/10.1093/acprof:oso/ 9780190260903.003.0007

Weinstein, R.S. (2016a). The California College Preparatory Academy Opens. In R.S. Weinstein \& F.C. Worrell (Eds.), Achieving College Dreams: How a University-Charter District Partnership Created an Early College High School (pp. 77-92). New York: Oxford University Press. doi.org/10.1093/acprof:oso/9780190260903.001.0001, doi. org/10.1093/acprof:oso/9780190260903.003.0004

Weinstein, R.S. (2016b). Forging a Partnership with Aspire Public Schools. In R.S. Weinstein \& F. C. Worrell (Eds.), Achieving College Dreams: How a University-Charter District Partnership Created an Early College High School (pp. 55-76). New York: Oxford University Press. doi.org/10.1093/acprof:oso/9780190260903.001.0001, doi. org/10.1093/acprof:oso/9780190260903.003.0003

Weinstein, R.S., Martin, J.F., Bialis-White, L.H., \& Sami, N. (2016). Tracking Student Indicators across Time. In R.S. Weinstein \& F.C. Worrell (Eds.), Achieving College Dreams: How a University-Charter District Partnership Created an Early College High School (pp. 185-208). New York: Oxford University Press. doi.org/10.1093/acprof:oso/ 9780190260903.001.0001, doi.org/10.1093/acprof:oso/9780190260903.003.0009

Weinstein, R. S., Sami, N., \& Mello, Z.R. (2016). Learning from Teacher-Student Advisories. In R.S. Weinstein \& F. C. Worrell (Eds.), Achieving College Dreams: How a UniversityCharter District Partnership Created an Early College High School (pp. 95-117). New York: Oxford University Press. doi.org/10.1093/acprof:oso/9780190260903.001.0001, doi.org/10.1093/acprof:oso/9780190260903.003.0005

Weinstein, R.S., \& Worrell, F.C. (Eds.). (2016a). Achieving College Dreams: How a University-Charter District Partnership Created an Early College High School. New York: Oxford University Press. doi.org/10.1093/acprof:oso/9780190260903.001.0001

Weinstein, R.S., \& Worrell, F.C. (2016b). Introduction - A University's Role in Education Reform. In R.S. Weinstein \& F.C. Worrell (Eds.), Achieving College Dreams: How a University-Charter District Partnership Created an Early College High School (pp. 3-32). New York: Oxford University Press. doi.org/10.1093/acprof:oso/9780190 260903.001.0001, doi.org/10.1093/acprof:oso/9780190260903.003.0001 
Weinstein, R. S., Worrell, F. C., Kaufman, G., \& Basri, G. (2016). Conclusion - The Power of a University-District Partnership. In R.S. Weinstein \& F.C. Worrell (Eds.), Achieving College Dreams: How a University-Charter District Partnership Created an Early College High School (pp. 359-387). New York: Oxford University Press. doi.org/10.1093/acpr of:oso/9780190260903.001.0001, doi.org/10.1093/acprof:oso/9780190260903.003.0017

Worrell, F. C., \& Weinstein, R.S. (2016). Epilogue. In R.S. Weinstein \& F.C. Worrell (Eds.), Achieving College Dreams: How a University-Charter District Partnership Created an Early College High School (pp. 389-395). New York: Oxford University Press.

Frank C. Worrell, Prof., born in 1960, Prof. at the University of California, Berkeley, Graduate School of Education.

E-Mail: frankc@berkeley.edu

Address: University of California, Berkeley, School Psychology Program, Graduate School of Education (MC 1670), 2121 Berkeley Way, Berkeley, CA 94720-1670, U.S.A. 